\title{
Defining Managerial Communication, Limitations and Challenges
}

Adela DRAGAN *

\begin{tabular}{l}
\hline \multicolumn{1}{c}{ A R T I C L E I N F O } \\
\hline Article history: \\
Accepted December 2019 \\
Available online December 2019 \\
\hline JEL Classification \\
D83, J53 \\
Keywords: \\
Communication, Managerial \\
communication, Definition, \\
interaction, Interactive process
\end{tabular}

\begin{abstract}
A B S T R A C T
The definition of managerial communication in the Romanian specialized works brings into question different aspects that characterize it and which are more or less typical of a definition. In these works, the main idea is that managerial communication is used as an instrument. We consider that through the elements it implies (categories of communication partners, messages, contexts etc.) and the implications it generates, managerial communication is a multifunctional and strategic interactive process through which verbally and non-verbally, the institution's activity, image and socio-professional interdependence are ensured, as well as its members' intellectual and emotional evolution.
\end{abstract}

(c) 2019 EAI. All rights reserved.

\section{Introduction}

A complex process and of a particular importance in the human evolution, through the development of the personality of individuals, of the culture of humanity as a whole, communication allows itself to be described and defined from different perspectives. Depending on the vision they have adopted, all theories so far have insisted on different aspects, out of which we list only a few in order to precisely highlight the multitude of facets of communication and the difficulties of a unitary definition, but also the possible contexts of exploitation of one or the other of the types of visions. Therefore, in defining communication, we will find aspects related to how information is transmitted from an emitter to a recipient, the intention behind a statement, the message that results from it, the role of the context in its interpretation, the implications of the status of the interlocutors (through the hierarchical relationships they generate, through the special characteristics of the respective interactions and of the discourse), the role of the non-verbal language in understanding a message, the emotional effect on the communication partners and on the relationship between them etc.

The existence of a multitude of elements to consider in defining communication has inevitably led to different theories, each serving some interests in explaining communication, that is, the way in which people send to each other information and messages, inevitably with different intentions (the transmission of information or messages in the absence of an intention being impossible or pathological). For example, the transmission of information derived from the wish to determine a feeling or an action, to contribute to the growth of the encyclopaedic universe of the person etc. Thus, the different theories serve the parameters concerned (sociological, psychological, ethnological or linguistic, etc.). Irina Stănciugelu et alii (2014: 45) write about the impossibility to contain the complex phenomenon of communication in a universal definition. A common note, however, seems to be that we talk about communication as a process: "All definitions given to human communication, regardless of the schools of thought they belong to or the orientations in which they belong, have at least the following common elements: communication is the process of transmission of information, ideas, opinions, beliefs, either from one individual to another, or from one group to another (...)" (ibidem: 23). Some of the multiple contents of communication are also presented by E. Dobrescu (2010: 119): "Communicating means interacting, agreeing, contradicting, negotiating, imposing your point of view, motivating, inspiring confidence, encouraging, criticizing etc." or "Communication means trust". (ibidem: 122), so relationship, connection with the other.

Because communication is intrinsic to human social existence and therefore implicit in all professional activities, it has also been analysed from the perspective of the situations that generate it and that influence the work process itself. Thus, the professional relations allowed to discuss communication at all institutional levels and of all the actors involved: management, managers at different hierarchical levels 
and employees among them. The fact that institutions are aware of the importance of communication between employees, especially in terms of the conflicts it can generate, and even the consequences of image outside the institution, has led to the regulation of the way of communication at institutional level through its own regulations and codes.

By its statute, a manager can be considered a landmark for the institution he manages and it becomes evident the importance of the way he communicates both inside and outside the institution, both of which can be analyzed as a professional competence, with immediate implications, sometimes in the long run, for the personal image and that of the institution. All these observations can show even without a thorough analysis, the problems that can be generated by the attempt to define managerial communication.

The importance of communication in the manager's activity is constantly emphasized and determines his concern for this component of his work. For example, Bâzu (2010: 15) argues that "Communication occupies a central place in the management process") and Cornescu et alii (2003: 199) consider that communication "is undoubtedly in the top five problems of a manager, because communication is one of his main concerns."

The fact that it can represent a strategic advantage can justify the interest that is assigned to it and all the attention it demands. The manager being asked to have multiple levels of competence, which require him to be, among others, "entrepreneur, problem solver, responsible for the allocation of resources or negotiator" (Dobrescu, 2010: 33), it is normal for him to care about the way in which he interacts, in which he expresses himself, empathizes or motivates and in which he creates an image. Therefore, he has to be interested in developing his communication skills.

Our work addresses to both theoreticians in the field of managerial communication, as well as to practitioners, managers, or other people having a management position, as well as future specialists, students or masters, doctoral students, for a good conceptualization and understanding of managerial communication.

What we propose is a highlight of the situation of defining managerial communication in the Romanian specialized works (Cândea, Rodica, Cândea, Dan, 1996 and 1998, Voicu, Monica, Rusu, Costache, 1999, Bâzu, Petru, 2010 and Dobrescu, Emilian, 2010) and a proposition of redefining it, covering as accurately as possible what managerial communication represents.

\section{Romanian definitions of the managerial communication. Current perspectives}

In the specialized Romanian works dedicated to managerial communication there are definitions based on how this communication is or how it should be put into practice, presenting the relationship between the management functions and the communication mode. Issues related to goals, strategy, communication functions, relationship between leadership and communication are discussed, in known forms, verbal or non-verbal, oral or written, in specific professional contexts, such as decision making, conflict status or recruitment and evaluation of the subordinates etc. (Cândea R., and Cândea, D. ,1998).

The problems of defining managerial communication are easily visible by the fact that definitions sometimes fail to be synthetic and bring together elements of description that are not typical of a definition. Such a case is represented by the proposition made by Monica Voicu and Costache Rusu (1999: 15), where we find a definition-description because we find almost everything that can be said about managerial communication - characteristics, status, and use. The authors' proposition is the following:

"Managerial communication is:

- a management tool with which the manager can exercise his specific attributes - provision, organization, training, coordination, control;

- part of the management process by which the manager understands his subordinates and is understood by them;

- a causal network where the "nodes" (managers and executors) are inter-conditioned in different directions and meanings, on direct and bypassed paths, using feedback whenever necessary;

- a process similar to decision making because in order to take place it is necessary to obtain, order, process and transmit information;

- an auxiliary of the management that puts into circulation information about the results of the decisions that return to the decision centre, thus making it possible to agree the execution with the objectives and the results with the planning;

a network of information flows (ascending, descending, horizontal);

- $\quad$ influenced by the abilities and the attitudes of the people directly involved;

- integrated in the organizational culture;

- involved in all the activities of a leader;

- of a dual nature: formal (official) communications whose existence is foreseen and whose orientation is in accordance with the hierarchical structure and informal (unofficial) communications that are based on social conditions and are born spontaneously within the organization;

oriented only to the transmission of messages and to the change of people's mentalities and their psychological adaptation to the chosen objectives; 
- also used in order to influence the behaviour and "preferences" of the employees and convince them that the objectives can be achieved.

As we can easily notice, the definition is focused on the idea of process and on the idea of instrument that managerial communication can represent.

Although the detailed aspects are correct, the presentation also contains a minimal typology, elements that influence the managerial communication and which are not normally part of a definition.

Another definition that is based on an enumeration of ways in which we can consider managerial communication is given by Bâzu (op. cit: 5-6), passing through a starting point, namely that we talk about communication as a relationship at the level of the entire organization, based on the exchange of messages with a defined purpose. Thus, "Managerial communication is a complex relationship between the employees of an organization, materialized in the realization of a two-way exchange of messages, information and opinions in order to achieve the set objectives. (...)

The managerial communication is:

- a management tool with which the manager can perform his specific functions: forecasting, organizing, staffing, training and control-regulation;

- a causal network in which the "nodes" (managers and subordinates) are inter-conditioned, using feed-back if necessary;

- an activity that helps the manager understand his subordinates and make himself understood by them;

- a process similar to decision making because in order to take place, it is necessary to obtain, process and transmit information;

- a network of information flows (ascending, descending, horizontal);

- a management auxiliary oriented not only to the design and transmission of messages, but also to the change of mentality and behaviour of the employees in order to achieve the set objectives.

The need to emphasize the usefulness of communication determines that sometimes the status of the instrument is presented according to the definition, the way it happens to E. Dobrescu (op. cit.: 13): "Managerial communication is, therefore, that type of communication practiced by a manager, representing a way of transmitting information at the managerial level, with the purpose of making efficient decisions in order to achieve the objectives set for that organization with maximum profitability. Managerial communication is also a management tool by which the company manager sends essential messages to the organization, its members, so that the information is well understood in order to achieve the organization's objectives." In the same way, Cândea R., Cândea D. (1996: 46) who state that "Managerial communication, as a form of inter-human communication, has certain particularities imposed not only by its purpose, objectives and role, but also by the organizational framework and organizational structure. This clarification helps us fix the idea that we are talking about managerial communication as a type of communication that does not undergo essential changes of human communication, but about a professional communication with its characteristics, coming from the specific objectives of the type of activity, from the status of the partner of communication and the context of its achievement.

If we refer to the contexts in which managerial communication is manifested, which we have mentioned above, it is obvious that these last definitions are not sufficiently comprehensive.

Another situation that we encounter concerns the status of the managerial communication as a "component of the organizational communication", "because it helps internally, that is everything related to the employees of the company, as well as externally, in relationship with its suppliers, investors etc., which, in the end, leads to the fulfilment of the company's objectives." Dobrescu (op. cit.: 14)

Different returns on the description of the managerial communication during the works dedicated to this subject are very frequent and indicate the difficulty of the definition process, by reference to the production contexts, the role, the intention and the effects of the managerial communication. Thus, in Dobrescu (ibidem: 26), we encounter other descriptive aspects subsequent to the definition by which we find that managerial communication is "a fundamental process of mutual interaction based on feed-back, in which managers at any level transmit ideas, feelings and decisions to their subordinates, having the possibility to check the way their message is received by them. It influences and modifies perceptions, attitudes, behaviours, feelings, opinions of individuals and groups and, therefore, constitutes a way by which people synergistically correlate their efforts." Communication also appears as "an important tool for implementing changes, strategies, having major implications on the management quality and efficiency." (ibidem)

The same instrument status can be found in Dobrescu (ibidem: 28) when he writes about managerial communication as "a management tool with which the manager can exercise his specific tasks: forecasting, training, organizing, coordinating, controlling and evaluating. Being part of the management process by which the manager understands his subordinates, making himself understood by them, managerial communication is oriented not only to the transmission of messages, but also to the change of mentalities and the psychological adaptation of the employees to the objectives of the organization. Managerial communication represents an auxiliary of the management that puts into circulation information about the 
outcome of the decisions, thus making it possible to reconcile the execution with the objectives and the results with the planning."

Cândea, R. and Cândea, D. (op. cit.: 37) also talk about the instrument, saying that "Communication becomes the harmonizing tool in the management of human resources, the basic tool of the manager in fulfilling his functions and in achieving the objectives of the organization." The various explanations regarding the importance of communication and its purposes allow us to highlight some aspects that invite to reflection in defining managerial communication. They may sometimes seem limitative and only need to be correlated with certain types of actions. For example, Bâzu (op. cit. 8-9) states that "The purpose of managerial communication in any organization is to achieve correct, efficient and effective information, both vertically and horizontally, in order to achieve optimal conditions of internal and external requests and in accordance with the established managerial and organizational objectives."

The idea of function or role of the managerial communication also appears in its description, respectively in the "image creation" and "forming a consciousness of belonging to the respective organization", or in "motivating employees" (Dobrescu, op. cit.: 41)

Other definitions (Cândea, R. and Cândea, D., op. cit.: 35) take into account the effect of the managerial communication and less the way in which it materializes: "The effective and efficient managerial communication is a factor of competitiveness, a strategic advantage of the organization." The tendency to eliminate a misunderstanding of managerial communication sometimes determines authors to rightly insist on what managerial communication is not, but without a description of its content, or on how it should not be practiced: "Communication becomes a philosophy management and not just a number of mechanical measures and actions." (ibidem: 37).

While trying to define managerial communication, we have also found different metaphorical tendencies that cannot serve as definitions, such as "The managerial communication is the vital flow that makes possible the performances of an organization" (Dobrescu, op. cit.: 107) or "As a state of mind and as a management instrument, the managerial communication is present in all aspects of the managers' work, ensuring the operationalization of the management functions, enhancing individual and collective performance, establishing fair and efficient relationships between employees both horizontally and vertically. It is essential for the environment, for its access to information sources." (ibidem: 26-27) It goes without saying that we can speak about communication as a state of mind only as a style exercise. Communication can be influenced by mood and can influence mood, but it is hard to talk about it as a mood. Understood as a working atmosphere in an institution, the mood can be an effect of communication and it is easy to understand that a good / pleasant atmosphere can be the consequence of good communication both as a whole and the managerial level.

These descriptions highlight the effects that managerial communication can produce at the behavioural and cognitive-emotional level. The reference to the emotional aspect that emerges from the presentation of managerial communication is important because it concerns the effect of communication on the working environment, which can be one of the motivational engines.

\section{Redefining the managerial communication}

Regarding all the aspects presented, we can point out that the tendency to talk about managerial communication as an instrument is justified because in all professions there is an emphasis on working tools, which must be known and used. However, seen as a whole as an institution-specific phenomenon, through the elements it implies (categories of communication partners, messages, contexts etc.), through the implications it generates, the managerial communication must be viewed in order to be defined as a process. It can be presented as a tool only from a practical point of view, from the perspective of the manager's auxiliaries. Presented as a means, as it sometimes appears, is perhaps too little.

Cândea, R. and Cândea, D. (op. cit.: 35) state that the emergence of a discipline that deals with managerial communication was born out of the need to "provide the manager with the optimal means of interaction in order to perform his functions and his roles." This clarification serves the idea of deepening the vision on the interactions in the manager's activity, especially from the perspective of the effects of these interactions, because they support both the actual activity and the connections among people, their own evolution.

In all his activities, the manager must activate his competences and abilities of economic strategist, psychologist, speaker, diplomat, evaluator, and use his ability to make decisions. By transmitting information with different purposes and multiple effects, engaging different partners and using different channels (by telephone, courier etc.) the manager generates and manages an entire process. Thus, we consider that we can speak of the managerial communication as a multifunctional and strategic interactive process that ensures verbally and non-verbally the activity of the institution, its image, its socio-professional interdependence, as well as the intellectual and emotional evolution of the members of the institution. This perspective of definition can support a better understanding of the complexity of this managerial activity, which can bring more efficiency and modernism, extremely useful in today's society. 


\section{Conclusions}

Studied in depth and broken down into all its segments, managerial communication can appear as the result of a very technical thinking in all the areas it manifests. Leadership abilities and experience can make it appear as a natural, non-rigid action. The entire activity of managerial communication is also a form of self-communication, resulting from both discourse and non-verbal elements - gestures, attitude, mimicry, and clothing, so assuming mastery of aspects of interactivity and image that are a source of professional force, through the symbolic power that they associate to the manager. The impact is a valuable one, by outlining the perception of the professional profile but also of the person behind that manager.

Directly valuable for a performing manager, managerial communication has a beneficial effect on the performance of the activity of the members of an institution, through its consequences generating results and professional aspirations. If the new technologies bring major changes in the evolution of managerial communication, the definition itself will surely undergo adjustments, in relation to these transformations generated by a dynamic that is only partially predictable.

\section{References}

1. Bâzu, Petre, Comunicare managerială, Rovimed Publishers Publishing House, Bacău, 2010

2. Cândea, Rodica, Cândea, Dan, Comunicarea managerială, Expert Publishing House, Bucharest, 1996.

3. Cândea, Rodica, Cândea, Dan, Comunicarea magerială aplicată, Expert Publishing House, Bucharest, 1998.

4. Cornescu, Viorel, Curteanu, Doru, Marinescu, Paul, Toma, Sorin, Management. De la teorie la practică. The University of Bucharest Press, 2003

5. Cristache, Mihaela, Managementul comunicării, Bren Publishing House, Bucharest, 2004.

6. Dobrescu, Emilian, Comunicarea managerială, Wolters Kluwer, Bucharest, 2010

7. Drăgan, Adela, Interdisciplinary support for professional communication: pragmalinguistic aspects of verbal politeness in International conference of management and industrial engineering vol 7/2015, 2015 pp. $633-652$

8. Lukács, Edith, Managementul resurselor umane, Europlus Publishing House, Galați, 2010.

9. Prutianu, Stefan, Manual de comunicare și negociere în afaceri. Vol 1, Comunicarea, Polirom Publishing House, Iași, 2000.

10. Stănciugelu, Irina, Tudor, Raluca, Tran, Adriana, Tran, Vasile, Teoria comunicării, Tritonic Publishing House, Bucharest, 2014.

11. Voicu, Monica, Rusu, Costache, ABC-ul comunicării manageriale, Danubius Publishing House, Brăila, 1999.

\section{Webography}

1. Adriana Bădescu, Codruţa Mirci, Gabriela Bögre, Managementului Resurselor Umane, 2008, Timișoara, Brumar http://www.islavici.ro/cursuriold/Managementul_Resurselor_Umane\%20-\%20curs.pdf

2. Cornescu, Viorel, Curteanu, Doru, Marinescu, Paul, Toma, Sorin, Management - de la teorie la practică. Editura Universității din Bucureși, București, 2003. 